\title{
詥 說
}

\section{商 店 街 の 変 質 作 用}

一一東京の周縁部池上」における一

田.中啓爾

\section{1. はしがを}

商店街の变質作用について，東京の周绿部における例をとりあげて論じて見よろ。 それには東京都の南部（大田区）の池上駅附近を対象とすることにしよう。その池上 駅は菒京急行電鉄池上線に属している。

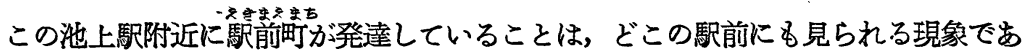
り，駅の改札口といらたげ一つの㹟い交通の関門に対する地位性の然らしめるところ である。この池上駅の附近には，開駅当時は全く店舖がなかつたのが，今日の繁栄を 来すに至つたことる，他に多く見る現象と等しい。この場合に，一つの改机口から出 入することを余儀なくさせられる多数の人々を相手にする商店街としては，改札口に 近い注ど有利であることもいらまでるない。そこで池上駅前には「池上銀座」があり， その土地柄相応のにぎやかな中枢商店街をなしている。

そして駅の改札口を中心として同心的に商店街の繁栄度か满らいで行くことも， 他に多く見る現象と等しく，改札口の出入者が次第に各方面の道路に沿了て分散し， その交通量力゙同心円的に減少する程度に比例していることもいらすでるない。

この場合に改札口から或る距離の地点に開駅以前の商店街があつたとしたら，駅前 の新興商店街とどんな関係をるつことになるかか間題である。

さて池上駅から 4.00 米を隔てた所に，池上本門奎の門前町があり，そこは池上駅の 開設前の商店街であつた。

そこで今ここに沲上駅前町と池上本門寺の門前町との関係を梌討することにしよろ。

\section{2. 池上本門寺の門前町}

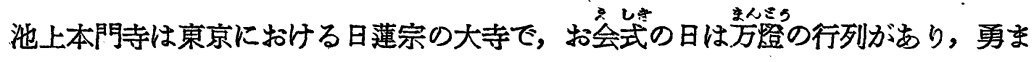


しい大鼓の音も聞かれ，東京の年中行事として有名て，この日は，一般の人々の参拝 も拉びただしい。寺は約20米の台地上に建てられていて，南の段下に門前町が発達し て，そこに広場がある。今見ると，戦㶤をまぬかれた地域には，石屋・花屋・酒屋

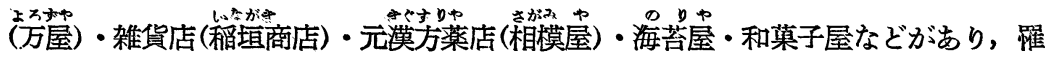

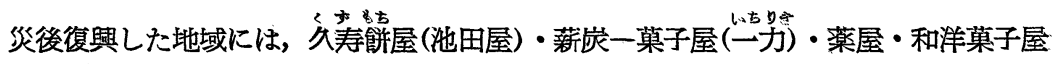
(西村)・洋装店などがある。万屋は瓦亘ではあるが，建築が古風であり，稲垣商店と 相模屋とは一見して異様のすがたが目につくがや营にトタンをかがせたものであり， 明治時代までの郊外の門前町の景観をしのぶことができる。門前町の指標としては， 石屋や花屋や茶屋や料理屋や宿屋や名物店などが考只れる。石屋と花屋は今もある。 他の石屋の跡には薬屋ができている。名物久寿餅屋は池田屋だけが焼跡に復興して営 業をつづけて，もとの面影を存しているが,浅野屋は池上駅前の広場に移転している。 それでも浅野屋は表看板には「宝暦元年創業,池上骂代の久寿鸰屋」としるし，屋内に は「大本山本門寺御用」の木札がかざつてある。しかし今の浅野屋は池田屋とちがい， 久寿飭以外の菒子やスマック゚アイスクリームを食べさせる程度に変つている。他の 名物であつたたちばな（日蓮上人の紋所にちなんだ）煎䬷屋（西村）は㜔跡に復興し たが，煎餅をやめて一般向の和洋菒子屋（西村）と变つている。元の浅野屋は西から の参詣者, 煎餅屋 (西村) は東からの参詣者を得意としていたが，今は参詣者は南 方の池上駅からのものが主となつたので，その道路にあたりかつ沲上門前町の広場に 面している池田屋だけが名物專門店として営業を持続している。

それでは粼理屋や宿屋はどうなつているであろろか。池上門前町の広場の正面に交 番と燎け残りの土蔵がある。ここはR 病院長の住宅の燅跡であるが，同院長はだしば

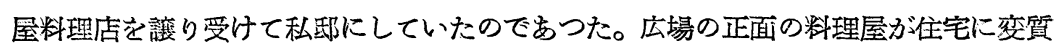
するほど参詣者に料理屋の必要性がなくなつたのである。広場に面している料理屋兼 宿屋の若松屋は，戦災を受けたままで復與していない。また料理店水茶屋の焼跡には， 洋装店が開かれている。苜魯不動の門前町の料理屋も戦災のまま復與しないが, 郊外 が都市化されたことと，交通が便利になりすぎたことは，門前町の料理屋や宿屋の変 質を余儀なくさせた。

さて池上門前町にある酒屋・雑貨屋・菒子屋・薬屋・薪炭屋などは，門前町に直接 関係のない生活必需品店である。江戸や明治時代の東京の郊外，池上村に住む農民に 
そつて，生活必需品の商店街が必要であつた。その求めに応じて発生した商店街が， 純門前町と複合して発達して来たものが池上本門寺の門前町であつた。万屋は門前町 の広場に直面していて，草分けの商店であることを思わされる位置にあり，今も酒・

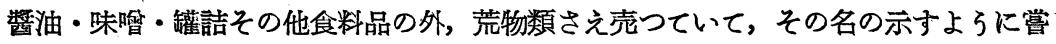
つては百貨を売つていたものが，他の商品店が附近に分業化して発生するにつれて， 酒類にかたよつた店となつたものと考えられる。隣の稻垣商店は雑貨店であるが，も そは油屋であつた。その油屋も胡麻油の製造所で，附近にとれる胡麻を原料とした農 村加工業から出発している。都市化が進んで胡麻が不足すると，他から原料をとりよ せて製油をつづけ，そのしぼつた油は，日本橋の問屋まで運んでいた。その返り荷と して，日本橋で手に入りやすい紙を仕入れて，紙販売もしていた。その後胡麻油の製 造は続けがたくなつたが、紙商売だけは残つた。それがさらにその後住民の需要に応 ずるため諸雑貨や煙草をるあわせて売る店と变つた。漢方薬店が廃業したのに代つて， 石屋の焼けた跡に，新に近代的な薬屋か開業したのは，薬屋が生活必需品店であるこ そを語つている。海苔の専門店が未だに残つていることは，周囲と何となく似つかわ しくない気がする。これは戦災をまねがれたから，習慣性で営業をつづけているに過 ぎないもので，焼跡に開業した薬屋・莎崖屋・和洋菒子屋・洋装店などは，これと異: なり純生活必需品店として出発しつつある。

\section{3. 周線商店街と中樞商店街}

そこでこの池上門前町が純生活必需品店に变質しつつあることを理解するため，池 上駅前町におけるこの門前町の地位を検討して見よう。

池上駅の改札口に向つて歩く道は，四方から集つて来ている。令のらち南から（池 上徳持町の南部以南) の通路と, 北から (久ど原町・卡池上町方面)の通路と, 東か. ら (堤方町方面)の通路とを対比して見よう。

池上駅前の広場に出て来る南加らの通路の踏切以南には, 魚屋 ( 2 戸) ・肉屋・酒屋・

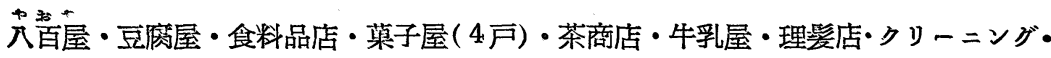
時計一眼鏡屋・吳服屋などが軒を並べている。これ等はいずれる生活必需品店である ことを示している。茶商店などは田口園という屋号をもつているが，菓子販売を兼ね ているのは，まだ茶の専門店として十分な商圈を持ち得ないからであろろ。時計など 
も修繥が主であることは，商圈の小ささを示す。この外にラジオ屋があるが，小规模 で修結が主である。このうち酒屋と，豆腐屋とは，向いの董地に新築したほどの新興 商店で，このように駅南の住民に対する最小限度の生活必要品街が発育しつつある現 状である。

この南からの通路に対し，北からの通路に沿ろ商店街を調べて見ると，稲荷橋を中 心として, 魚屋・肉屋・八百屋・菓子屋 ( 3 戸) ・茶商店・理珐店とパーマネント・ク リーニング・日用雑貨店・薪炭店・鞉屋・洋装店・自転車屋・助産婦などの店が一団 をなしている。ここの茶商店も専門店でなくて煙草屋を兼ねており，肉屋も菒子屋を 兼ねている。理髮店は一般にパーマネントに先立つて発生するものであるが，都市の . 周縁居住地においては，同時に現われることが少くない。靴屋は生活必需店の要素と して次第に頭をあげて来た。靴屋が最初修繥屋から始をることは，時計屋などの場合 と同類型である。ここの鞉屋が狭い新装の店であることは，横浜市中山駅前町（港北 区）の靴屋がはじめは借りた軒下で修繥していたものが，最近狭い新装店を別な所に 開いたのと似ている。この通のうちに二階建の住宅があり，その戸裂と壁しとるに1 米半の大きな下歌の画が二つ㖶いてあつて，「キクヤ」と太く下䭾屋の名も書いてある が，下䭾屋が廃業になつているのは，靴に代られた時勢を物語つている。助産婦る最 小限度の商店街に殆ど必ず伴弓職業の一つといえる。

以上によつて南からの通路と，北からの通路とに沿うて発生しつつある生活必需品 商店街の共通性が自から明かになつてくる。

ころして池上駅前の広場には，銀行を中心として各種の店が並び，山本園と称する 茶の専門店もあれば, 薬屋も 3 戸あり，パチンコ屋もある。さらにここから西へ延び ている「池上銀座」には，「履物と崟」屋がさし向いに4戸もあり，本屋も，カメラ 屋も，三河屋という大きなパン屋るある。駅前町の周縁部の通路沿いに見られない種 類の商店や旧種類の重複商店が密集している中枢商店街は，その繁栄度の高さを示し ている。この地域の住民は日常の生活必需品は，主として，池上駅前町への通路で買 い求め, それ以上の品は, 駅前広場や「池上銀座」で買い求め, 更に高級品は 2 キロ 半隔てた (バスで行く) 大森駅前町か， 2 キロ隔てた（電車で行く）蒲田駅前町で買 い,さらに最高級品は本場の銀座で買つている。 


\section{4. 結列}

以上のような四重の生活圏（買物圏）が構成されていることを考えると，今の池上 の門前町は，東からの通路に沿了生活必需品商店街としての地位しか持つていないこ とになる。しかも東から（大森方面）は新道が旧道にほぼ平行して設けられ，新しい 商店街がとこに発展しつつあるので，旧道に沿う池上閒前町は，生活必需品商店街と しても極めて貧弱な商圈しか持つことができず，万屋時代よりもわずかに一歩前進し た近代商店街という外はない。洋装店が只服店と入れ代りつつある現在，南道には呉 服店, 北通には洋装店があるのに対し，東道の旧道では洋装店の新にできたことが, わずかにこの通の近代化といえる程度にすぎない。

江戸時代から明治時代にかけて，この池上地方の中枢商店街であつた池上本門寺の 門前町が，このよろに池上駅前町の発生と発展によつて, 沲上駅前町の周縁部の生活: 必需品街に变質したことは，他の地域にも見られる商店街の变質作用の結果である。

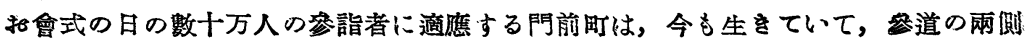
に名物の大踣を賈る露店がならび，その上各種職業店で當日だけ大呚を霞るものさこ ある。

（杲京文理科大學名翼敉授）

\section{人口地圖の諸問題}

—その作図理論に就いて——

織田武 雄

(1)

「人口とは一定の地域内に於ける個人の絵量である」と定義されているように，人口: には常に地域と云う地理的な概念が含をれているために，地理学に於ては，人口は地 表に於ける人交現象を数的に考察する第一の基調と考えられ，また地表に於ける諸地 域の自然的・人交的諸現象の関係を最も直截に表示する綜合的な徽表と看做されてい る。それ故に人口の地理的分布を表現する人口地四は，人交地理図に於て最子重要な 


\title{
English Abstracts
}

\section{THE TRANSFORMATION OF A SHOPPING THOROUGHFARE IN IKEGAMI}

\author{
By KEIJI TANAKA
}

The Present study deals with a district near Ikegami R. R. Station located in the southern part of Tokyo.

Notwithstanding there had been no shop near the R. R. Station at the time that it was built, a shopping center is growing there nowadays in a concentric circle with the platform-wicket of the Station as its central point. It is becoming the heart of the district as a newlyrising shopping center. This fact had best be considered with reference to Ikegaimi Monzencho Street, former center of the district.

(1. ) Monzencho (front of a gate) Street of Honmonji Temple of Ikegami. Ikegami Honmonji Temple, an important temple of the Nichiren sect, is crowded by people on the occasion of the anniversary of the death of Nichiren. On both sides of the road to the temple, many street-stalls are opened selling drums which are noted products of the place. Besides in areas not devastated by air raids stone-dealers' shops, florists' shops, restaurants, hotels and souvenir shops are seen carrying on business as before. Although this Monzencho still retains certain aspects of a suburban-town in the latter part of the Meiji period, it can also be recognized that it is transforming into a street on both sides of which are sold only the necessaries of life.

(2.) Circumferential shopping thoroughfares and the pivotal shopping centers. In Ikegami and the areas surrounding it the following four life (shopping)-spheres can be observed: 
a. The pivotal shopping center in front of the R.R. Station (where the necessaries of life are sold).

b. The circumferential shopping thoroughfares(where the necessaries of minimum life are sold).

c. The shopping thoroughfares within the $2 \mathrm{~km}$. circle(where expensive articles are sold).

d. The shopping center in the heart of the town (where the most expensive articles are sold).

Monzencho previously mentioned now has but the standing of a shopping_thoroughfare where the necessaries of minimum life are sold. It is a'street having advanced only one step from the time of general dealers. On the other hand, there appeared in front of the R.R. Station a new shopping center depriving Monzencho of the topmost position and becoming a new pivot of the district's life-spheres.

(3.) Conclusion. The fact that Monzencho of Ikegami Honmonji Temple that had been pivotal in Ikegami and its surrounding areas from the Yedo epoch to the latter part of the Meiji period is now transforming into a less important shopping street where the necessaries of the newlyrising shopping center that has grown in front of Ikegami R. R. Station. Such a phenomenon will be observed, more or less frequently; in other districts too.

\section{THE LAND-ALLOCATION IN TANYO VILIAAGE IN THE PROVINCE OF OWARI}

\section{By KANJI KAGAMI}

Tanyo Village in the province of Owari is an all but pure farm-village located in the north of Nagoya City at the distance of about eight kilo- 